\title{
Culinary Model Innovation on Some Bitter Melon Cultivar (Momordica Charantia L.) Cultivar with High Pectin, Protein, and Diosgenin Characteristics
}

\author{
Ummi Rohajatien $^{1 *}$ Mazarina Devi ${ }^{2,}$ Titi Mutiara $\mathrm{K}^{3 .}$ \\ ${ }^{1,2,3}$ Department of Industrial Technology, Engineering Faculty, Malang State University \\ *Corresponding author: Ummi.rohajatien.ft@um.ac.id; ummir99@gmail.com
}

\begin{abstract}
The culinary model of bitter melon that has developed so far has been directed towards functional food and is widely processed using conventional methods that are boiled, steamed or sauted. This conventional processing method is also taught to students of the Catering Education Study Program at several universities and at the Vocational High Schools in Indonesia. This study aims to investigate the physico-chemical characteristics, especially for pectin and protein as well as organoleptic characteristics of pare fruit innovation. This research was conducted by observing and experimenting on several bitter gourd models. The results of the study revealed that the changes that occurred in the pare fruit culinary innovation were found in the processing method and product results. Results Bitter melon culinary innovations have the characteristics of a longer shelf life and are processed using conventional methods. The creativity of processing pare fruit product innovation is sourced from the study of food science and technology that has not been widely studied as a basic science in culinary learning as part of culinology. The research also revealed that bitter melon with physico-chemical characteristics high in pectin and high in protein after undergoing culinary processing did not experience significant changes. This is interesting to be used as one food source that can prevent several kinds of degenerative diseases such as coronary heart disease and cancer.
\end{abstract}

Keywords: culinary model, culinology, innovation

\section{INTRODUCTION}

The culinary model of bitter melon (Momordica charantia, L) which has existed in several countries in Asia such as India, Japan, Malaysia and Indonesia has almost the same characteristics. Utilization of bitter melon fruit as a culinary for southern Japanese society for laxative, laxative and worm medicine (Okabe et al., 1980), in India bitter melon extract is used as a diabetic medicine, rheumatic medicine, liver disease drug and lymphatic medicine (Dixit et al., 1978). The report, published by the World Health Organization in 2002, has been known since 1992, the number one killer in Indonesia causing mortality is cardiovascular disease. One of the most common cardiovascular diseases in Indonesia is coronary heart disease (CHD). Coronary heart disease is ranked first of the ten most causes of death in Indonesia. Modern human lifestyles that tend to have more nutrition and less physical movement dramatically increase the incidence of irregular metabolism, including diseases related to obesity, diabetes mellitus, dysilipidemia and hypertension. Finally, much effort is invested in detecting bioactive compounds in food which can reduce the risk of metabolic irregularities including antioxidant diets aimed at reducing risk factors for cardiovascular disease (WHO, 2006).

Pare fruit (Momordica charantia, L) is one of the fruit vegetables in Indonesia which contains many beneficial components and antioxidants including bioactive compounds with an excellent role in biological activities such as antidiabetic, anti hypercholesterolamic, antiobesity, antitumor, anti inflamatory, analgesic, antiviral and anti depressants (Kumar, et al. 2011). Bitter melon with various potential bioactive components contained therein is one of the potential functional food sources.

Bitter melon culinary developed until now is quite a lot of variety and can provide a role in functional food, but lacks a long shelf life. The problem of shelf life that often occurs in the bitter gourd model requires a new breakthrough through a study of innovative bitter gourd models that have a longer shelf life and can still provide a role as one of the functional food sources.

\section{METHODOLOGY}

Primary data on the physico-chemical characteristics of bitter melon consisting of levels, carbohydrates, pectin and protein, were carried out with food analysis procedures using the AOAC method (2010). Furthermore, the research was conducted by observing the variety of bitter melon and culinary innovations that have been studied and written the results of the research as a final project (thesis) by students of Gastronomy Education State University of Malang as secondary data. 
process of processing bitter melon innovation is based on the nature of bitter melon as one of the functional food sources and food processing technology that is in accordance with the nature of bitter melon fruit. Food processing technology has developed quite broadly to allow for innovations in the discussion, one of which is culinology. Culinology is a branch of science that has a lot to say about culinary based on food processing technology. As a branch of science today culinary plays a strategic role in advancing science and in the culinary learning process. Processing of bitter melon in some of its culinary shows no significant difference at $\alpha=0.05$ to its components including pectin and protein components. The results of the analysis of the characterization of pectin content and protein content of fruit and culinary bitter melon are presented in table 2 . While table 1 contains the characterization of carbohydrate, protein and pectin content and water content of bitter melon from 4 cultivars, namely fresty cultivar, nawaty, dynasty and raden cultivar. Changes that occur from pare fruit culinary innovation lies in the processing method and product storage time. The

Table 1. Nutritional content $(\mathrm{db})$ of bitter melon at the age of harvest

\begin{tabular}{|l|l|l|l|l|l|l|}
\hline No & $\begin{array}{l}\text { cultivar } \\
\text { compontent }\end{array}$ & $(\%)$ & fresty & nawaty & dynasti & raden \\
\hline 1. & Carbohidrat & $\%$ & $73.9 \pm 1.6 \mathrm{~b}$ & $63.2 \pm 1.3 \mathrm{a}$ & $11.5 \pm 0.4 \mathrm{~d}$ & $9.9 \pm 0.2 \mathrm{~b}$ \\
\hline 2. & Pectin & $\%$ & $15.4 \pm 0.2 \mathrm{~b}$ & $13.1 \pm 0.4 \mathrm{a}$ & $15.2 \pm 0.5 \mathrm{~b}$ & $21.3 \pm 1.1 \mathrm{c}$ \\
\hline 3. & Protein & $\%$ & $17.3 \pm 1.3 \mathrm{~b}$ & $15.7 \pm 0.9 \mathrm{ab}$ & $14.8 \pm 1.3 \mathrm{ab}$ & $14.1 \pm 1.3 \mathrm{a}$ \\
\hline 4. & Water content & $\%$ & $93.7 \pm 1.7 \mathrm{a}$ & $93.5 \pm 1.2 \mathrm{a}$ & $93.4+1.9 \mathrm{a}$ & $94.1 \pm 1.3 \mathrm{a}$ \\
\hline
\end{tabular}

The content of the protein component of bitter melon which is $12.8 \%-16.6 \%$ is almost the same as the crude protein content of bitter melon in the vegetable category $(12.2 \%+0.3 \%)$, but lower than the protein of young bitter melon leaves and higher than the bitter melon leaves that have been yellowing of research results by Min et al. (2009). The content of bitter melon fruit in this study was still quite large, which was around $(93.7+1.7) \%$. The amount of water content of bitter melon fruit is higher than the water content of bitter melon leaves in the results of Zhang Min's research which ranged at $(73.5+1.2) \%$. High water content still allows the growth of microorganisms that can cause enzymatic reactions and can change the components inside (Andreas and Harrison, 2006). Pectin is a soluble fiber that has the ability to retain water and can form a thick liquid in the digestive tract so that it inhibits the contents of the digestive tract with digestive enzymes that result in reduced absorption of food substances. The levels of bitter melon in this study ranged from $12.7 \%$ to $22.4 \%$.

Table 2. Kadar nutrisi (db) buah olahan pare

\begin{tabular}{|l|l|l|l|l|l|l|}
\hline No & $\begin{array}{c}\text { Bitter } \\
\text { melon }\end{array}$ & $\%$ & steamed & boiled & sauteed & $\begin{array}{l}\text { Culinary } \\
\text { innovation }\end{array}$ \\
\hline 1. & carbohidrate & $\%$ & $48.2 \pm 1.4 \mathrm{ab}$ & $51.2 \pm 2.3 \mathrm{~b}$ & $42.9 \pm 2.1 \mathrm{a}$ & $61.42 \pm 0.9 \mathrm{c}$ \\
\hline
\end{tabular}




\begin{tabular}{|l|l|l|l|l|l|l|}
\hline 2. & Pectin & $\%$ & $15.5 \pm 1.8 \mathrm{a}$ & $24.6 \pm 2.6 \mathrm{~b}$ & $28.5 \pm 2.6 \mathrm{~b}$ & $19.6 \pm 0.7 \mathrm{a}$ \\
\hline 3. & Protein & $\%$ & $14.9 \pm 0.8 \mathrm{~b}$ & $29 \pm 1.5 \mathrm{c}$ & $2.4 \pm 0.9 \mathrm{a}$ & $10.3+0.6 \mathrm{~b}$ \\
\hline 4. & Water content & $\%$ & $91.5 \pm 1.4 \mathrm{c}$ & $96.2 \pm 1.5 \mathrm{~d}$ & $84.6 \pm 1.4 \mathrm{~b}$ & $15.3 \pm 0.7 \mathrm{a}$ \\
\hline
\end{tabular}

The content of the protein component of bitter melon which is $12.8 \%-16.6 \%$ is almost the same as the crude protein content of bitter melon in the vegetable category $(12.2 \%+0.3 \%)$, but lower than the protein of young bitter melon leaves and higher than the bitter melon leaves that have been Yellowing of research results by Min et al. (2009). The content of bitter melon fruit in this study was still quite large, which was around $(93.7+1.7) \%$. The amount of water content of bitter melon fruit is higher than the water content of bitter melon leaves in the results of Zhang Min's research which ranged at $(73.5+1.2) \%$. High water content still allows the growth of microorganisms that can cause enzymatic reactions and can change the components inside (Andreas and Harrison, 2006). Pectin is a soluble fiber that has the ability to retain water and can form a thick liquid in the digestive tract so that it inhibits the contents of the digestive tract with digestive enzymes that result in reduced absorption of food substances. The levels of bitter melon in this study ranged from $12.7 \%$ to $22.4 \%$.

The highest levels of carbohydrates and pectin are found in bitter melon cooked by the steamed and boiled method, while the highest pectin content is found in bitter melon cooked by the boiled and sauteed method. The method of cooking by steaming produces the highest levels of total sugar than the two methods of cooking by boiling and steaming. Table 2 also reveals that the cooking method that has the greatest influence on the nutritional content of bitter melon is cooking with boiling. Boiled cooking methods produce the best levels of protein, carbohydrates, and pectin. While the method of cooking with pan-fried produce high levels of pectin. Based on the results of this study, it is known that the cooking of bitter melon with boiled method has a better nutritional content than the two cooking methods steamed and sauteed. These results are the same as the results of a study by Lunn and Buttris (2007) who revealed that cooking by boiling is the best method for cooking potatoes. With the boiled method can produce folic acid content that is not significantly different. But the results are somewhat different in broccoli where the method of cooking with steamed is the best cooking method in providing quality nutrients to broccoli, especially on carotene and folate levels.

\section{CONCLUSION}

The research revealed that bitter melon with physicochemical characteristics high in pectin and high in protein after undergoing culinary processing did not experience significant changes. This is interesting to be used as one food source that can prevent several kinds of degenerative diseases such as coronary heart disease and cancer.

\section{REFERENCES}

[1] Andreas, E. C. and Harrison, J.A. So easy to preserve (Bulletin 989). Cooperative Extension Service, university of Georgia, Athens. 2006

[2] AOAC. Official Methods of Analytical. Association of Official Analysis Chemists Washington DC, USA. 2010.

[3] Dixit VP, Kimnna P, Bhargava SK. 1978. Effects of Momordica charantia L. Fruit extract on the Testicular Function of Dog. J. Med. Plant Res. 34:280.

[4] Hadiyati, H.N.2012. Pengaruh metode pengolahan boiling, streaming dan sauting terhadap kadar $\beta$-carotene pada buah Par Momordica charantia dan aplikasinya pada Kuliner. Skripsi.

[5] Kumar, R.S., J.Ashih, N. Satish. 2011. Momordica charantia Linn.: a mini review. International Journal of Biomedical Research 2(11): $579-587$

[6] Lunn, J., \& Buttriss, J. L. (2007). Carbohydrates and dietary fibre. Nutrition Bulletin, 32(1), 21-64.

[7] Min Z.., et al., Effect of maturity stages and drying methods on the retention of selected nutrients and phytochemicals in bitter melon (Momordica charantia) leaf. J Food Sci; 74(6): C441-8: (2009).

[8] Okabe H, Miyahara Y, Yamauchi T, Miyahara K, Kawasaki T. 1980. Studies on the Constituents of MomordicacharantiaL. Isolation and Characterization of Momordicoside A and B, Glycosides of $a$ Pentahydroxy Cucurbitane Triterpen..Chem. Pharm. Bull 28: 2753.

[9] WHO. 2006. Reseach guidelines for evaluating the savety and efficacy of herbal medicines. Manila: WHO Regional Officer for Western Pacific. p. 35

[10] Williams JF, Ng NO. 1971. Variation within Momordica charantia L. The Bitter Gourd (cucurbitaceae).Ann. Bogoriensis, 6: 111. 